\title{
APPLICATION OF HIGH-PERFORMANCE LIQUID CHROMATOGRAPHIC METHOD FOR SIMULTANEOUS DETERMINATION OF RACECADOTRIL AND OFLOXACIN IN THEIR PHARMACEUTICAL DOSAGE FORM
}

\author{
Fathy M. Salama, Nasr M. El-Abasawi, Ahmed El-Olemy, Mohamed Kamel* \\ Department of Pharmaceutical Analytical Chemistry, Faculty of Pharmacy, Al-Azhar \\ University, Cairo, Egypt. \\ *Corresponding author: Mohamed.kamel@azhar.edu.eg
}

\begin{abstract}
Racecadotril and ofloxacin are co-formulated for treatment of acute symptomatic diarrhea. In the present work RP-HPLC method was developed for simultaneous determination of racecadotril and ofloxacin in the combined dosage form. An isocratic separation was carried out on BDS Equisil C18 (150 X $4.6 \mathrm{~mm}, 5 \mu \mathrm{m}$ particle size) reversed phase column with a mobile phase consists of water and acetonitrile in the ratio of $(20: 80 \% \mathrm{v} / \mathrm{v})$ and pH 3 maintained by $0.1 \%$ ortho phosphoric acid. The flow rate was 1 $\mathrm{ml} / \mathrm{min}$ and UV detection at $230 \mathrm{~nm}$. The linear regression analysis of the calibration graphs showed a good linear relationship over a concentration range of $5-25 \mu \mathrm{g} / \mathrm{ml}$ with main recovery percent $100.06 \pm 0.952$ and $99.93 \pm 0.798$ for racecadotril and ofloxacin, respectively. The proposed method was validated according to $\mathrm{ICH}$ guidelines, and has been successfully applied for simultaneous determination of both drugs in both bulk and commercial dosage form.
\end{abstract}

Keywords: Racecadotril, Ofloxacin, Simultaneous determination, International conference on harmonization.

\section{INTRODUCTION}

Racecadotril, also known as acetorphan, is an antidiarrheal drug which acts as a peripherally acting enkephalinase inhibitor. Unlike other opioid medications used to treat diarrhea, which reduce intestinal motility, racecadotril has an antisecretory effect it reduces the secretion of water and electrolytes into the intestine (Eberlin et al., 2012). Chemically racecadotril is benzyl N-[3-(acetylsulfanyl)-2-benzylpropanoyl]glycinate, Figure 1 (O'Neil et al., 2001).It is official in BP (Pharmacopoeia, 2010).

Ofloxacin is a synthetic antibacterial agent of the fluoroquinolone class (Nelson et al., 2007). Chemically ofloxacin is ( \pm )-9-fluro-2,3-dihydro-3- methyl-10-(4-methyl-1piperazinyl)-7-oxo-7H-pyrido[1,2,3-de]-1,4-benzoxazine-6 carboxylic acid, Figure 1 (O'Neil et al., 2001). It is official in BP, IP, USP, and EP (Pharmacopoeia, 2010; Pharmacopoeia, 2010 ; Pharmacopoeia, 2008; Pharmacopoeia, 2004). 
The review of literature revealed that various analytical methods involving spectrophotometry, HPLC have been reported for determination of racecadotril in single dosage form (Akifulhaque et al., 2012; Annapurna et al., 2014; Bh et al., 2016; Kharodiya., 2015; Patel et al., 2012; Raju et al., 2011; Sankar and Arulantony, 2017; Tank et al., 2012; Vetrichelvan and Prabakaran, 2007; Yuanyuan et al., 2007). Several analytical methods including spectrophotometry, HPLC, electrophoresis, chemilumiscence have been reported for ofloxacin in single form and in combination with other drugs (Alnajjar, 2013; Bhusari and Chaple, 2009; Bindaiya et al., 2010; Chen et al., 2014; Hancu et al., 2012; John et al., 2015; Liu et al., 2015; Nebsen et al., 2013; Patel Sanket and Patel Satish, 2011; Patel Satish and Patel Natavarlal, 2011; Prabhu et al., 2010; Premanand et al., 2010; Puranik et al., 2010; Rane and Shinde, 2009; RP-HPLC, 2010; Singh et al., 2011; Sivakumar et al., 2012; Sun et al., 2010; Vinay et al., 2009; Wang et al., 2009; Zhu et al., 2017).

The present paper describes a simple, accurate and precise method for simultaneous determination of racecadotril and ofloxacin. The developed method was validated in accordance with ICH guidelines and successfully employed for the assay of racecadotril and ofloxacin in their combined dosage form (ICH guidelines, 2005).

\section{Experimental:}

\section{Materials and Chemicals:}

Pure racecadotril $(99.35 \%)$ and ofloxacin (99.55\%), the purity was checked by applying the official method described in the British Pharmacopeia (Pharmacopoeia, 2010), were kindly supplied by National Organization for Drug Control and Research, Giza, Egypt. Enuff- $\mathrm{O}^{\circledR}$ powder for oral suspension was purchased from the Indian pharmaceutical market Batch No. E1705004 (labeled to contain $15 \mathrm{mg}$ racecadotril and $50 \mathrm{mg}$ ofloxacin per $5 \mathrm{ml}$ of constituted suspension). Acetonitrile , HPLC grade (Sigma Aldrich, Germany),orth-phosphoric acid (El-Nasr company, Egypt). Whatman filter paper $\mathrm{N}^{\mathrm{o}} 41$.

\section{Instruments:}

HPLC Analytical (Agelint, USA), equipped with Diode-array UV-Visible detector and auto sampler injector. The chromatographic analysis was carried out using (Thermo ChromQuest 4.2.34, version 3.1.6) data analysis program.

\section{Standard solutions:}

A Standard stock solutions of racecadotril and ofloxacin were prepared separately by dissolving the appropriate amount of pure powder of the drugs in acetonitrile to yield a final concentration of $1 \mathrm{mg} / \mathrm{ml}$. Further, working solutions were obtained by serial dilutions of stock solutions with acetonitrile. 


\section{Chromatographic conditions:}

At ambient temperature, isocratic separation was carried out on a BDS Equisil C18 column (150 mm X $4.6 \mathrm{~mm}$; $5 \mu \mathrm{m}$ particle size) using a mobile phase consists of water and acetonitrile in the ratio of $(20: 80 \% \mathrm{v} / \mathrm{v}), \mathrm{pH} 3$ maintained by $0.1 \%$ ortho phosphoric acid. The mobile phase was degassed before pumping at the flow rate of $1 \mathrm{ml} / \mathrm{min}$. Before injecting the solution, the column was equilibrated for at least 30 minutes with the mobile phase flowing through the system. The injected volume of the standard solution was $20 \mu 1$ and UV detection at $230 \mathrm{~nm}$. The Solutions and the mobile phase were freshly prepared and filtered using membrane filter at the time of use.

\section{Procedures:}

\section{Construction of calibration graphs:}

Accurately measured volumes $(0.5-2.5 \mathrm{ml})$ of racecadotril and ofloxacin standard solutions $(100 \mu \mathrm{g} / \mathrm{ml})$ were transferred into two separate series of $10 \mathrm{ml}$ volumetric flasks and diluted to volume with the acetonitrile to obtain final concentrations of $(5-25 \mu \mathrm{g} / \mathrm{ml})$ for both drugs. Twenty $\mu \mathrm{l}$ aliquots were injected (in triplicate) and eluted with the mobile phase under the optimum chromatographic conditions. The average peak areas of racecadotril and ofloxacin were plotted versus the corresponding drug concentrations in $\mu \mathrm{g} / \mathrm{ml}$ to get the calibration graphs. Alternatively, the corresponding regression equations were derived.

\section{Assay of the laboratory-prepared mixtures:}

Aliquots of standard solutions equivalent to $(100 \mu \mathrm{g} / \mathrm{ml})$ of racecadotril and ofloxacin were transferred into a series of $10 \mathrm{ml}$ volumetric flasks keeping the ratio between them as in the pharmaceutical preparation $(1: 3.3 \mathrm{v} / \mathrm{v}$ respectively). The solutions were diluted to the volume with the acetonitrile and mixed well. Twenty $\mu 1$ aliquots were injected (in triplicate) and eluted with the mobile phase under the optimum chromatographic conditions. The mean percent recoveries of each drug were calculated using the corresponding regression equation.

\section{Application to pharmaceutical preparation:}

Enuff-O ${ }^{\circledR} 10$ gm powder for $30 \mathrm{ml}$ suspension (each $5 \mathrm{ml}$ of constituted suspension labeled to contain $15 \mathrm{mg}$ of racecadotril and $50 \mathrm{mg}$ ofloxacin). A portion of powder equivalent to $1.667 \mathrm{gm}$ was accurately weighed, transferred to $100 \mathrm{ml}$ volumetric flask and the volume was made up to $50 \mathrm{ml}$ with acetonitrile. The solution was shaken vigorously for about 10 minutes, then sonicated for 30 minutes and filtered. The volume was completed to $100 \mathrm{ml}$ with acetonitrile to produce a stock solution labeled to contain $0.15 \mathrm{mg} / \mathrm{ml}$ of racecadotril and $0.5 \mathrm{mg} / \mathrm{ml}$ of ofloxacin,respectively. Different concentrations of racecadotril and ofloxacin have to be obtained by dilutions of the stock solution of each one 
with the acetonitrile to covering the concentration range. Twenty $\mu 1$ aliquots were injected and eluted with the mobile phase under the optimum chromatographic conditions. Contents of both drugs were calculated using the corresponding regression equation.

\section{RESULT AND DISCUSSION :}

To date, The literature survey revealed that there is no separating technique had been developed for the determination and quantification of racecadotril and ofloxacin in its combined dosage forms. Only one spectrophotometric method (absorbance correction) were reported for simultaneous estimation of racecadotril and ofloxacin Figure 2 (Kharodiya, 2015).

Simultaneous determination of co-formulated drugs is an important part in the field of pharmacy as it reduces the effort and time of extraction. This fact promotes our interest in the development of a simple and sensitive reversed phase HPLC method for the simultaneous quantitative determination of both drugs.

The HPLC technique has been chosen due to its ability to determine quantitatively many individual components present in mixture by single analytical procedure without preliminary separation. . The developed method if compared to the reported method, it has the advantage of being more sensitive, Furthermore it doesn't need extra mathematical processing steps as in spectroscopic methods.

\section{Method development and optimization:}

The chromatographic conditions were carefully optimized to determine the most optimum chromatographic parameters required for good separation and quantitative determination for both racecadotril and ofloxacin.

Firstly, the selection of the optimum wavelength was carried out to provide maximum sensitivity for both racecadotril and ofloxacin. By trial, a wavelength of $230 \mathrm{~nm}$ had been selected since it provided a maximum sensitivity for both racecadotril and ofloxacin.Then, different developing isocratic systems with different composition and ratios were tried for separation using $\mathrm{C} 18$ packing as a stationary phase. Isocratic elution exhibits some advantages over the gradient one, such as greater simplicity, lower cost, simpler instrumentation and no need of column re equilibration between consecutive injections.

The flow rate of the mobile phase is also very important parameter in the separation of the studied drugs. So, the effect of the flow rate and $\mathrm{pH}$ were studied consequently, the flow rate of $1 \mathrm{ml} / \mathrm{min}$ is the optimum and $\mathrm{pH} 3$ is the best of choice since it keeps the drugs in its unionized form to increase hydrophobicity. Hence, the separation and resolution were improved. 
A mixture of [acetonitrile and 1\% ortho-phosphoric acid in water $(\mathrm{pH} 3)$ in the ratio of (80: 20, v/v)] was used as the mobile phase at a flow rate of $1 \mathrm{ml} / \mathrm{min}$ to exhibit good separation (reasonable resolution).

By optimization of the previous significant chromatographic condition, a chromatogram of racecadotril and ofloxacin was obtained with well-defined symmetrical peaks. In this chromatogram, both racecadotril and ofloxacin were separated with good resolution and their corresponding peaks were developed in retention times of $1.643 \pm 0.017$ and 2.094 \pm 0.021 minutes for racecadotril and ofloxacin respectively, as shown in Figure 3.

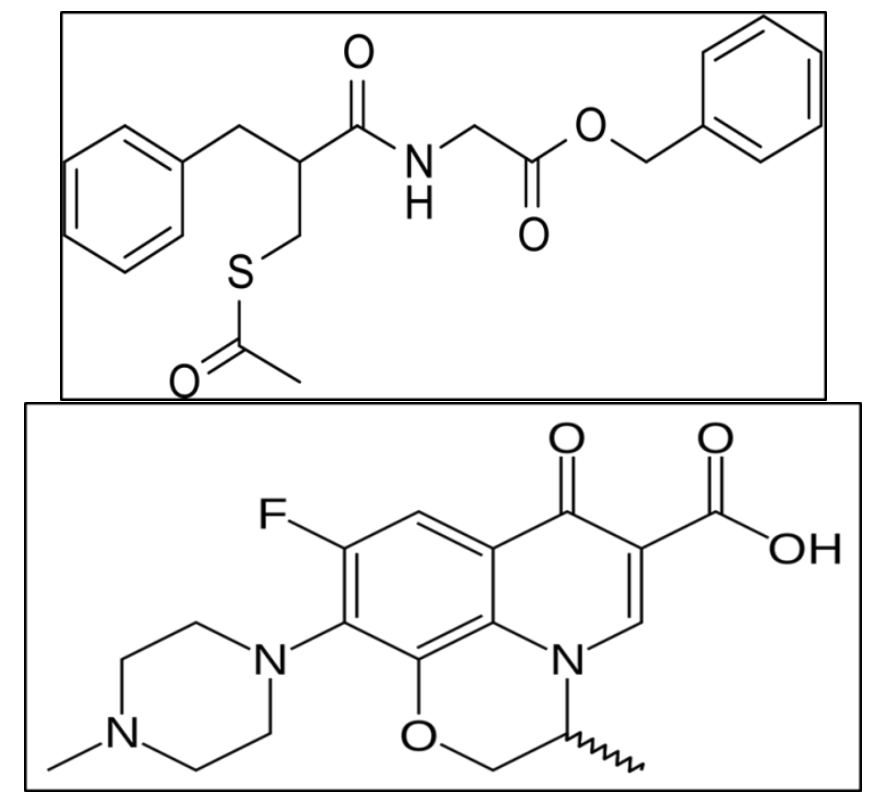

(a)

(b)

Figure 1: Structure formula of (a) Racecadotril and (b) Ofloxacin. 


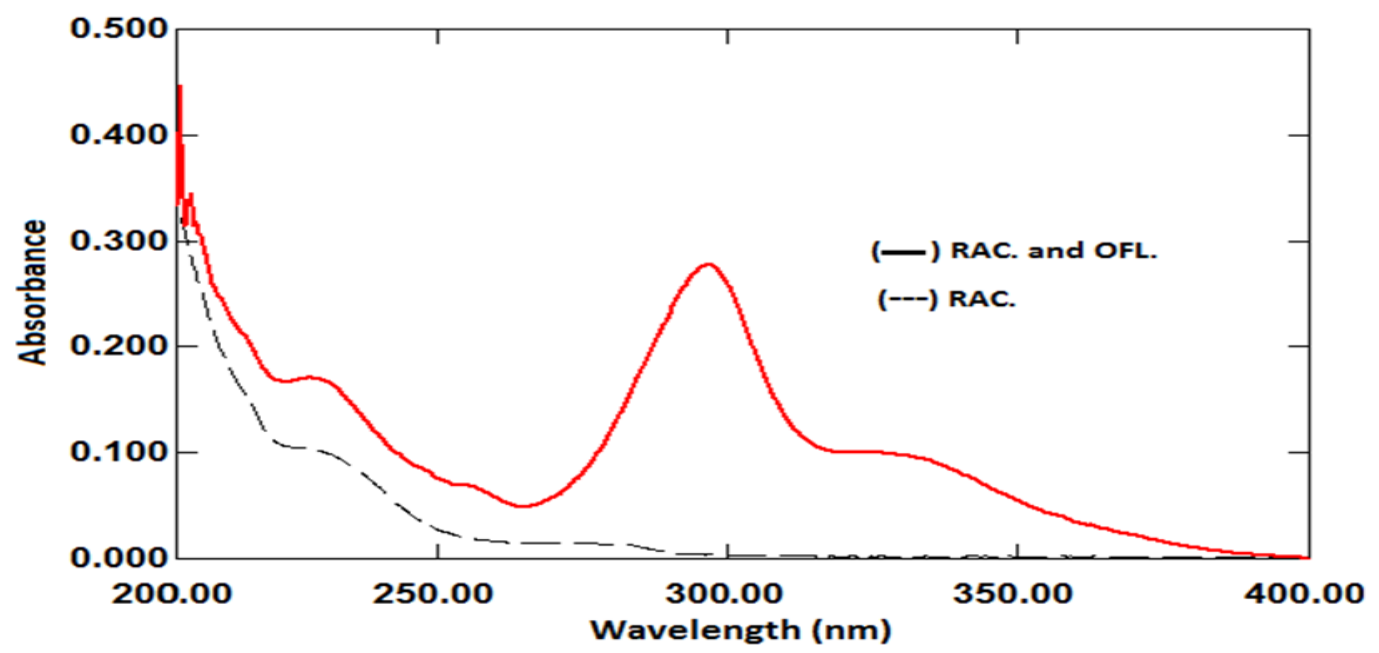

Figure 2:UV Absorption spectra of mixture of racecadotril $(24 \mu \mathrm{g} / \mathrm{ml})$, ofloxacin (24 $\mu \mathrm{g} / \mathrm{ml})$ and racecadotril $(24 \mu \mathrm{g} / \mathrm{ml})$ in methanol.

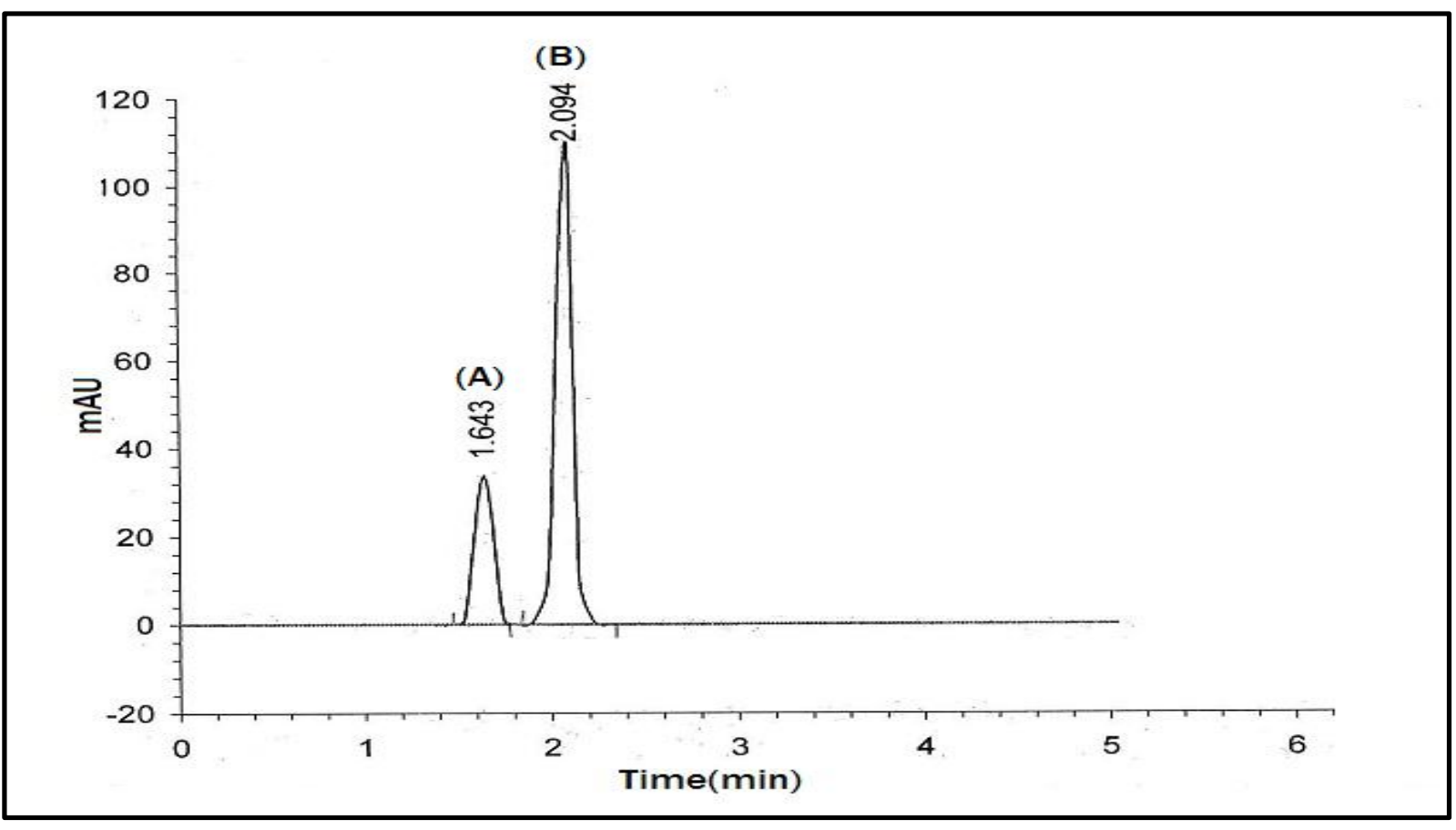

Figure 3: HPLC Chromatogram of racecadotril (A), $(20 \mu \mathrm{g} / \mathrm{ml})$ and ofloxacin (B), (20 $\mu \mathrm{g} / \mathrm{ml})$ at $230 \mathrm{~nm}$. 


\section{Method validation:}

Validation of the described methods was performed in a compliance with International Conference of Harmonization ICH guidelines (ICH guidelines,2005).

\section{Linearity and range:}

Under the described experimental conditions, the calibration graphs were constructed in the ranges of $5-25 \mu \mathrm{g} / \mathrm{ml}$ for both drugs by plotting the average areas of the chromatographic peaks versus drug concentrations in $\mu \mathrm{g} / \mathrm{ml}$ for both racecadotril and ofloxacin. Linearity ranges, regression equations, intercepts, slopes and coefficient of determination of the calibration data were presented in Table 1.

\section{Limits of detection and quantitation:}

The limit of detection (LOD) and the limit of quantitation (LOQ) were calculated according to ICH guidelines from the following equations:

$$
\begin{aligned}
& \mathrm{LOD}=3.3 \sigma / \mathrm{S} \\
& \mathrm{LOQ}=10 \sigma / \mathrm{S}
\end{aligned}
$$

Where, $\sigma$ is the standard deviation of y-intercepts of regression lines and $\mathrm{S}$ is the slope of the calibration curve.

The standard solutions of racecadotril and ofloxacin were analyzed using the developed method and minimum detectable and quantifiable limits were measured, the results are given in Table 1.

\section{Accuracy:}

Accuracy of the proposed method was assessed by applying the proposed procedure for triplicate determination of three concentration levels $(5,10,15 \mu \mathrm{g} / \mathrm{ml}$ for each drug). The mean percent recovery revealed excellent accuracy as shown in Table 1.

\section{Precision:}

\section{Repeatability:}

Triplicate determinations of standard drug solutions at three different concentrations of racecadotril and ofloxacin within one day using the proposed method. The resultant of standard deviations was measured, as shown in Table 1. 


\section{Intermediate precision:}

Triplicate determinations of standard drug solution at three different concentration levels of racecadotril and ofloxacin on three successive days using the proposed method. The $\%$ RSD was calculated and was found very satisfactory, as shown in Table 1.

Table (1): Regression and validation parameters of the proposed HPLC method.

\begin{tabular}{|c|c|c|c|}
\hline \multicolumn{2}{|c|}{ Parameters } & Racecadotril & Ofloxacin \\
\hline \multicolumn{2}{|c|}{ Wavelength (nm) } & 230 & 230 \\
\hline \multicolumn{2}{|c|}{ Linearity range $(\mu \mathrm{g} / \mathrm{ml})$} & $5-25$ & $5-25$ \\
\hline \multicolumn{2}{|c|}{ - Regression Equation } & $y *=b x *+a$ & $y^{*}=b x * * a$ \\
\hline \multicolumn{2}{|c|}{ - Slope (b) } & 8.1403 & 26.2401 \\
\hline \multicolumn{2}{|c|}{ - Intercept (a) } & -0.4948 & 2.2585 \\
\hline \multicolumn{2}{|c|}{ Coefficient of determination $\left(\mathbf{r}^{2}\right)$} & 0.9999 & 0.9999 \\
\hline \multicolumn{2}{|c|}{$\operatorname{LOD}(\mu \mathrm{g} / \mathrm{ml})$} & 0.825 & 0.782 \\
\hline \multicolumn{2}{|c|}{$\operatorname{LOQ}(\mu \mathrm{g} / \mathrm{ml})$} & 2.500 & 2.371 \\
\hline \multicolumn{2}{|c|}{$\operatorname{Accuracy}(\% \mathbf{R}) * * *$} & $100.06 \pm 0.952$ & $99.93 \pm 0.798$ \\
\hline \multirow{2}{*}{$\begin{array}{c}\text { Precision } \\
(\% \mathbf{R S D})^{* * * * *}\end{array}$} & Repeatability & 0.914 & 0.890 \\
\hline & $\begin{array}{c}\text { Intermediate } \\
\text { precision }\end{array}$ & 1.299 & 1.008 \\
\hline
\end{tabular}

* Peak area of RAC or OFL.

** Concentration of RAC or OFL in $\mu \mathrm{g} / \mathrm{ml}$.

***Average of nine determinations (triplicate determination of three concentration level).

$* * * * \% \mathrm{RSD}$ of \%Recovery of nine determinations (triplicate determination of three concentration level).

\section{Specificity:}

By visual inspection of the standard chromatogram, assay sample chromatogram, demonstrated that the separation of two drugs has a good resolution within suitable analysis time. To check the interference from the excipients present in the dosage form, the specificity of the proposed method was checked by applying the standard addition 
technique by addition of known quantities of the studied drugs in their pure form to already analyzed commercial tablet and the percent recovery of the pure added of three experiments was calculated. Satisfactory results were obtained in good agreement with the label claim, indicating no interference from excipients and additives, as shown in Table 2.

Table 2: Quantitative determination of both Racecadotril and Ofloxacin in Enuff-O ${ }^{\circledR}$ oral suspension by HPLC method using standard addition technique:

\begin{tabular}{|c|c|c|c|c|c|}
\hline Drug & $\begin{array}{l}\text { Pharmaceutical } \\
\text { taken }(\mu \mathrm{g} / \mathrm{ml})\end{array}$ & $\begin{array}{l}\text { Pharmaceutical } \\
\text { found }{ }^{*}(\mu \mathrm{g} / \mathrm{ml})\end{array}$ & $\begin{array}{c}\text { Pure added } \\
(\mu \mathrm{g} / \mathrm{ml})\end{array}$ & $\begin{array}{l}\text { Pure found }^{* * \pi} \\
(\mu \mathrm{g} / \mathrm{ml})\end{array}$ & \%Recovery \\
\hline \multirow{3}{*}{ 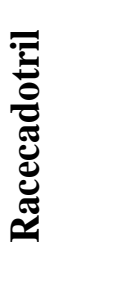 } & \multirow{3}{*}{10} & \multirow{3}{*}{9.95} & 10 & 10.09 & 100.99 \\
\hline & & & 20 & 19.85 & 99.26 \\
\hline & & & 30 & 29.90 & 99.67 \\
\hline \multicolumn{5}{|c|}{ Mean $\pm \%$ RSD } & $99.97 \pm 0.736$ \\
\hline \multirow{3}{*}{ 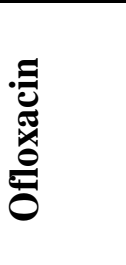 } & \multirow[b]{3}{*}{10} & \multirow[b]{3}{*}{10.06} & 10 & 10.00 & 100.06 \\
\hline & & & 20 & 19.92 & 99.64 \\
\hline & & & 30 & 30.20 & 100.68 \\
\hline \multicolumn{5}{|c|}{ Mean $\pm \%$ RSD } & $100.13 \pm 0.519$ \\
\hline
\end{tabular}

*Average of five experiments.

**Average of three experiments.

\section{System suitability:}

System suitability parameters were applied to a representative chromatogram to confirm that, the system is working correctly during the analysis operation. The final system suitability test parameters for the method were presented in Table 3 . 
Table 3: System suitability results for the determination of Racecadotril and Ofloxacin by the proposed HPLC method.

\begin{tabular}{|l|c|c|c|}
\hline \multicolumn{1}{|c|}{ Parameters } & Racecadotril & Ofloxacin & Reference value \\
\hline Retention time $\left(t_{\mathbf{R}}\right)$ & $1.630 \pm 0.017$ & $2.097 \pm 0.021$ & --- \\
\hline Retention factor $\left(K^{\prime}\right)$ & 1.143 & 1.594 & $1-10$ \\
\hline Theoretical Plates $(\mathbf{N})$ & $\varepsilon 0 Y^{\prime}$ & 5244 & $>2000$ \\
\hline Tailing factor $(T)$ & 1.01 & 1.09 & $<2$ \\
\hline Resolution factor $(R s)$ & \multicolumn{2}{|c|}{2.678} & $>2$ \\
\hline
\end{tabular}

Robustness:

It was evaluated by slight changes in the chromatographic conditions such as flow rate $( \pm 0.1 \mathrm{ml} / \mathrm{min}$.) and mobile phase contentration. In each case, only one parameter was changed while other conditions were kept constant. These minor changes did not affect the separation and resolution of racecadotril and ofloxacin, confirming the reliability of the proposed method. The results are given in Table 4.

Table 4: Robustness results for the determination of Racecadotril and Ofloxacin by the proposed HPLC procedure:

\begin{tabular}{|c|c|c|c|c|c|c|c|}
\hline \multicolumn{3}{|c|}{ Parameters } & \multicolumn{2}{|c|}{$\begin{array}{c}\text { Retention time } \\
\left(\mathbf{t}_{\mathbf{R}}\right)\end{array}$} & \multicolumn{2}{|c|}{$\begin{array}{c}\text { Tailing factor } \\
\text { (T) }\end{array}$} & \multirow[t]{2}{*}{$\begin{array}{c}\text { Resolution } \\
\text { (R) }\end{array}$} \\
\hline & & & RAC & OFL & RAC & OFL & \\
\hline \multirow{3}{*}{\multicolumn{2}{|c|}{ 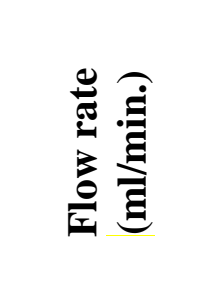 }} & 0.9 & 1.644 & 2.091 & 1.057 & 1.125 & 2.452 \\
\hline & & 1 & 1.630 & 2.081 & 1.012 & 1.094 & 2.522 \\
\hline & & 1.1 & 1.614 & 2.067 & 1.003 & 1.055 & 2.631 \\
\hline \multirow{3}{*}{ 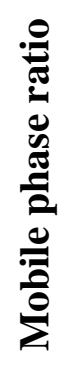 } & \multirow{3}{*}{ 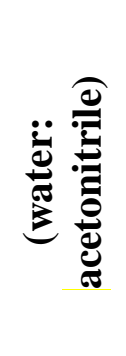 } & $22: 78$ & 1.646 & 2.072 & 1.026 & 1.055 & 2.749 \\
\hline & & $20: 80$ & 1.639 & 2.086 & 1.015 & 1.078 & 2.396 \\
\hline & & 18:82 & 1.627 & 2.094 & 1.009 & 1.117 & 2.225 \\
\hline
\end{tabular}




\section{Application:}

The proposed method was successfully applied for the simultaneous determination of racecadotril and ofloxacin in Enuff- $\mathrm{O}^{\circledR}$ oral suspension without interference of the excipients and additives and without prior separation. The obtained results were statistically compared to those obtained by the reported method (Kharodiya, 2015). No significant differences were found by applying t-test and F-test at $95 \%$ confidence level, as shown in Table 5.

Table 5: Determination of Racecadotril and Ofloxacin in Enuff-O ${ }^{\circledR}$ oral suspension by the proposed HPLC method and the repoted methods.

\begin{tabular}{|c|c|c|c|c|}
\hline \multirow{2}{*}{ Parameters } & \multicolumn{2}{|c|}{ Proposed HPLC method } & \multicolumn{2}{|c|}{ Reported method* [39] } \\
\hline & Racecadotril & Ofloxacin & Racecadotril & Ofloxacin \\
\hline Mean & 99.63 & 100.23 & 100.45 & 100.13 \\
\hline$\%$ RSD & 0.709 & 0.493 & 0.658 & 1.046 \\
\hline $\begin{array}{c}\text { Number of } \\
\text { measurements }\end{array}$ & 5 & 5 & 5 & 5 \\
\hline Student's $t$-test & $\begin{array}{c}1.441 \\
(2.306)^{* *}\end{array}$ & $\begin{array}{c}0.537 \\
(2.306)^{* * *}\end{array}$ & & \\
\hline$F$-value & $\begin{array}{c}1.933 \\
(6.388)^{* * *}\end{array}$ & $\begin{array}{c}1.242 \\
(6.388)^{* * *}\end{array}$ & & - \\
\hline
\end{tabular}

"UV Spectrophotometric method (absorbance correction) for determination of racecadotril by substrating absorbance of ofloxacin from total absorbance of sample at $231 \mathrm{~nm}$ ( $\lambda$ max of racecadotril). Ofloxacin concentration was determined directly from calibration plot by measuring absorbance at 323.40 ( $\lambda \max$ of ofloxacin), where racecadotril shows zero absorbance (Kharodiya, 2015).

** The values in parenthesis are the tabulated values of " $t$ "and " $F$ " at $(\mathrm{P}=0.05)$.

\section{Conclusion:}

From the above discussion, we can conclude that the proposed method was found to be accurate, precise and sensitive for simultaneous determination of racecadotril and 
ofloxacin in both bulk and commercial dosage form. The proposed method suitable for routine analysis and quality control laboratories.

\section{REFERENCES}

European Pharmacopoeia, 4th Edn, Vol-II (2004);Published in accordance with convention on the elaboration of European Pharmacopoeia.

United State Pharmacopoeia, 32th Edn (2008); The United State Pharmacopeial Convention, Washington DC, Board of Trustees.

Validation of Analytical Procedure: Text and Methodology, ICH Harmonized Tripartite Guideline, Q2 (R1) (2005); 1-13.

Akifulhaque, M., Nasare, M., Hasanamrohi, S., Satish, J., Kumar, J., and DIWAN, V. P. (2012). Stability Indicating Rp-Hplc Method For The Estimation Of Racecadotril In Pharmaceutical Dosage Form. Journal of Cell \& Tissue Research 12.

Alnajjar, A. O. (2013). Simultaneous determination of ofloxacin and cefixime in tablet formulation using capillary electrophoresis. Journal of Liquid Chromatography \& Related Technologies 36, 2687-2697.

ANNAPURNA, M. M., Narendra, A., and SAHU, A. (2014). Development and Validation of a Stability-Indicating RP-HPLC Method for Analysis of Racecadotril in Pharmaceutical Dosage Forms. Chemical Science Transactions 518-529, 3 .

Bh, C. N. R., Rao, G. D., and Sikharam, R. (2016). UV and Two Derivative Spectrometric Methods for Determination of Racecadotril in Tablet Formulation. Biosciences Biotechnology Research Asia 5, 747-752.

Kharodiya, M. A. L. (2015). Simultaneous Estimation Of Racecadotril And Ofloxacin In Combined Tablet Dosage Form.

Bhusari, K., and Chaple, D. (2009). Simultaneous spectrophotometric estimation of ofloxacin and ornidazole in tablet dosage form. Asian Journal of Research in Chemistry 2, 60-62.

Bindaiya, S., Bankey, S., and Jain, D. (2010). Simultaneous determination of nitazoxanide and ofloxacin in tablet by ultraviolet spectrophotometry (dual wavelength method). International Journal of ChemTech Research 2, 11-15. 
Chen, B., Zhang, Y., Xie, H. L., Chen, Q. M., and Mai, Q. H. (2014). Chiral separation of ofloxacin enantiomers by microchip capillary electrophoresis with capacitively coupled contactless conductivity detection. Journal of the Chinese Chemical Society 61, 432-436.

Eberlin, M., Mück, T., and Michel, M. C. (2012). A comprehensive review of the pharmacodynamics, pharmacokinetics, and clinical effects of the neutral endopeptidase inhibitor racecadotril. Frontiers in pharmacology 3, 93.

Hancu, G., Rusu, A., Simon, B., Boia, G., and Gyéresi, Á. (2012). Simultaneous separation of ciprofloxacin, norfloxacin and ofloxacin by micellar electrokinetic chromatography. Journal of the Brazilian Chemical Society 23, 1889-1894.

John, P., Azeem, W., Ashfaq, M., Khan, I. U., and Razzaq, S. N. (2015). Stability indicating RP-HPLC method for simultaneous determination of piroxicam and ofloxacin in binary combination. Pakistan journal of pharmaceutical sciences 28.

Liu, W., Guo, Y., Li, H., Zhao, M., Lai, Z., and Li, B. (2015). A paper-based chemiluminescence device for the determination of ofloxacin. Spectrochimica Acta Part A: Molecular and Biomolecular Spectroscopy 137, 1298-1303.

Nebsen, M., Elsayed, G. M., AbdelKawy, M., and Elkhateeb, S. (2013). Determination of ofloxacin and dexamethasone in Dexaflox eye drops through different ratio spectra manipulating methods. Bulletin of Faculty of Pharmacy, Cairo University $51,175-184$.

Nelson, J. M., Chiller, T. M., Powers, J. H., and Angulo, F. J. (2007). Fluoroquinoloneresistant Campylobacter species and the withdrawal of fluoroquinolones from use in poultry: a public health success story. Clinical Infectious Diseases 44, 977-980.

O'Neil, M., Smith, A., Heckelman, P., and Budavari, S. (2001). The Merck Index-An Encyclopedia of Chemicals, Drugs, and Biologicals. Whitehouse Station, NJ: Merck and Co. Inc 767, 4342.

Patel Sanket, A., and Patel Satish, A. (2011). Dual wavelength spectrophotometric method for simultaneous estimation of ofloxacin and cefpodoxime proxetil in tablet dosage form. Asian Journal of Pharmacy and Life Science ISSN 2231, 4423.

Patel Satish, A., and Patel Natavarlal, J. (2011). Development and validation of RPHPLC method for simultaneous estimation of cefixime trihydrate and ofloxacin in tablets. International Journal of Pharm Tech Research 3, 1958-1962. 
Patel, Y., Sen, A., Shah, B., and Seth, A. (2012). Development And Validation Of New Analytical Method For Quantitative Estimation Of Racecadotril As An Active Phamaceutical Ingredient By RP-HPLC. Pharma Science Monitor 3.

Pharmacopoeia, B. British Pharmacopoeia Commission, London,. 6th Edn; Vol-II, 2010.

Pharmacopoeia, I., Vol. III (2010). Government of India Ministry of Health \& Family Welfare Published by The Indian Pharmacopoeia Commission, Ghaziabad.

Prabhu, S., Amirtharaj, R. V r.and Senthilkumar, N. (2010). Simultaneous RP-HPLC method development and validation of cefixime and ofloxacin in tablet dosage form. Asian Journal of Research in Chemistry 3, 367-369.

Premanand, D., Senthilkumar, K., Senthilkumar, B., Saravanakumar, M ‘.and Thirumurthy, R. (2010). A validated RP-HPLC method for simultaneous estimation of nitazoxanide and ofloxacin in pharmaceutical formulation. Der Chemica Sinica 1, 1-5.

Puranik, M., Bhawsar, D., Rathi, P., and Yeole, P. (2010). Simultaneous determination of ofloxacin and ornidazole in solid dosage form by RP-HPLC and HPTLC techniques. Indian journal of pharmaceutical sciences 72,513 .

Raju, B., Delhiraj, N., and Rao, G. D. (2011). Spectrophotometric methods for the determination of Racecadotril in bulk and pharmaceutical dosage forms. Asian Journal of Research in Chemistry 4, 548-550.

Rane, V. P., and Shinde, D. B. (2009). Simultaneous High-Performance Liquid Chromatographic Determination of Nitazoxanide and Ofloxacin in Tablet Formulation. Eurasian Journal of Analytical Chemistry 4, 304-313.

RP-HPLC, T. D. F. B. (2010). Method development and validation for the simultaneous estimation of ofloxacin and ornidazole in tablet dosage form by RP-HPLC. methods $1,78-83$.

Sankar, M. S., and Arulantony, S. (2017) .New spectrophotometric method for the determination of racecadotril in pharmaceutical dosage forms. International Journal of Drug Research and Technology 3, 6.

Singh, H., Sharma, C., Ankalgi, A. D., Agal, S., and Ranawat, M. (2011). Spectrophotometric methods for simultaneous determination of nitazoxanide and ofloxacin in combined bulk and pharmaceutical formulations. International Journal of PharmTech Research 3, 118-123. 
SIVAKUMAR, C., Gupta, S., Chandan, A. K., Gunturu, C., and Indracanti, M. (2012) .Determination of cefixime and ofloxacin by ratio spectra and zero crossing difference spectrophotometry. International Journal of Pharmacy \& Pharmaceutical Sciences 4, 118-123.

Sun, H., Chen, P., and Wang, F. (2010). A novel enhanced chemiluminescence system with Ag (III) complex for the determination of ofloxacin and levofloxacin in pharmaceutical preparation and biological fluid. Analytical Letters 43, 2234-2245.

Tank, P., Zanwar, A., Seth, A., and Kumar, S. (2012). Development Of New Analytical Methods For Quantitative Estimation Of Racecadotril As An Active Pharmaceutical Ingredien By Uv Spectrophotometer. Int J Pharm Sci Res 3, 14951497.

Vetrichelvan, T., and Prabakaran, S. (2007). New spectrophotometric methods for the determination of racecadotril in bulk drug and capsules. Indian Journal of Pharmaceutical Sciences 69, 307.

Vinay, K., Revanasiddappa, H., Divya, M. R., and Rajendraprasad, N. (2009). Spectrophotometric determination of ofloxacin in pharmaceuticals and human urine. Eclética Química 34, 65-78.

Wang, Y., Baeyens, W. R., Huang, C., Fei, G., He, L., and Ouyang, J. (2009). Enhanced separation of seven quinolones by capillary electrophoresis with silica nanoparticles as additive. Talanta 77, 1667-1674.

Yuanyuan, Z., Jie, L., Ping, L., and Jianfen, Z. (2007). Quantitative Determination of Racecadotril in Racecadotril Dry Suspension by RP-HPLC [J]. China Pharmaceuticals 12 .

Zhu, B., Xu, S., Guo, X., Wei, L., Yu, J., and Wang, T. (2017). Use of various $\beta$ cyclodextrin derivatives as chiral selectors for the enantiomeric separation of ofloxacin and its five related substances by capillary electrophoresis. Journal of separation science 40, 1784-1795. 
تطبيق طريقة الكروماتوغرافيا السائلة عالية الأداء لتحديد المتزامنة لسباق السكاروتريل والأوفلوكساسين في شكل جرعة الاواء الاء

فتحي محمد سلامة ، نصر محمد العبساوي ، أحمد العلمي ، محمد كامل

قسم الكيمياء التحليلية الصيدلية ، كلية الصيدلة ، جامعة الأزهر ، القاهرة ، مصر.

الخلاصة:

راسيكادوترل و اوفلكساسين يتم صياغتهما بشكل مشترك لعلاج الإسهال الحاد الأعر اض.

في العمل الحالي ، تم تطوير طريقة RP-HPLC من أجل التحديد المنزامن لراسيكادريل و أوفلوكساسين في شكل جر عة مشتركة.

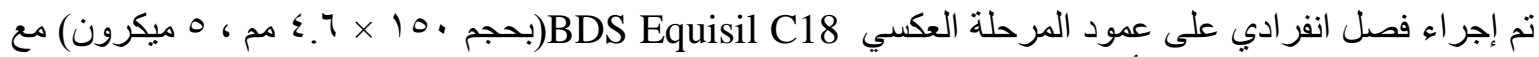

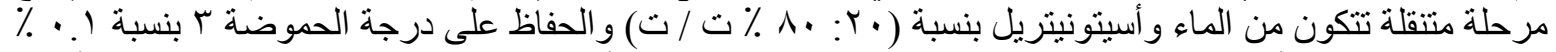

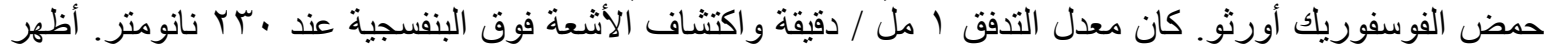

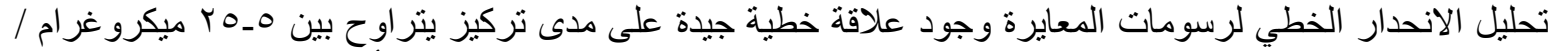

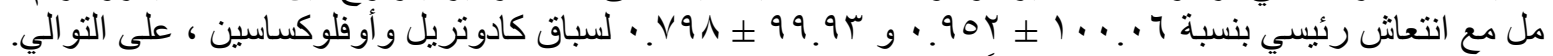

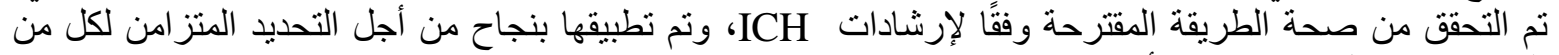
العقاقير في شكل جر عة سائبة أو تجارية. 